\title{
Prehistory and History: The Long Record of Foodways
}

\section{1 \\ Prehistory: From Hunting to Agriculture}

Our earliest records of Central Asian dining are of hunting kills, including that 45,ooo-year-old mammoth. By that time, people had reached remote parts of Mongolia, likely the last area to be settled. ${ }^{1}$ The "Paleolithic diet" in Central Asia was, so far as we know, meat — no doubt all parts of the animals. Like modern Siberian hunter peoples, they would have eaten everything from brains to feet, and from intestines and stomach contents to hide and tail. Scavenging predator kills, no matter how long dead, was no doubt important. Presumably, fish, fruit, seeds, and roots were devoured. Modern devotees of "paleo diets" might not have relished quite all this, but the general rule was that one had to eat everything and anything, given the chance. Hunting probably contributed to the decline of the larger, less abundant animals, such as mammoths.

After the end of the Ice Age, hunter-gatherers lived by hunting, fishing, and gathering wild plants on what became the steppes and in the valleys. A maze of poorly known and thinly populated groups defies summary here.

Agriculture advanced from the Near East and possibly India; from Eastern Europe; and from China. Near Eastern traditions related to the fast-developing ones of Mesopotamia expanded and differentiated in Iran and spread rapidly in the southwest Eurasian heartland. In Europe, early agriculture was associated with the Linearbandkeramik (LBK) cultural tradition, which spread very rapidly over an enormous area in 4500-5500 BCE. Related cultures (notably the Dniepr-Don complex) spread agriculture into the steppes. Agriculture began its explosive spread through the central and northern parts of Europe and the Eurasian heartland, with cultures of this general type. ${ }^{2}$ It is quite possible that this reflects the expansion of languages - not Indo-European ones at this early date. A wonderful introduction to the botany of ancient Central Asia has recently emerged: Fruit from the Sands by Robert Spengler. ${ }^{3}$

1 Holder (2019), "Humans Migrated to Mongolia Much Earlier than Previously Believed," Phys. org, Aug. 16.

2 Cunliffe, By Steppe, Desert, and Ocean.

3 Spengler (2019), Fruit from the Sands. 
The major crops that got into the Eurasian heartland early were wheat and barley. All the common domestic animals went with them, and the area soon added the horse to the domestication list. It is also quite possible that Inner Asia had previously added the dog; the dog was domesticated 15,000, or more, years ago, somewhere in Eurasia.

Meanwhile in China (or, more accurately, what later became China) pottery was already very old; it had been invented before 16, oо BCE. Agriculture, first primarily millet, then wheat and, of course rice, developed more slowly than in the West but soon became intense and important both in the Chinese North and South. The Chinese also domesticated some water plants such as water chestnuts which assumed early importance, although they are not major foods today. Despite such achievements, a variety of Western cultural advances, from sheep and goat domestication to bronze technology, and onward to such things as war chariots, were late in arriving. Writing may represent stimulus diffusion from the West, but more likely it was an independent invention in China. Similarities with early Mesopotamian writing seem purely accidental.

\section{Prehistory: Domestication}

True domestication is defined as genetic change in plant and animal stock, such that the domesticated form is genetically different from anything in the wild. In this sense, the first such domestication took place in the Near East about 9500-10,500 years ago, when people domesticated wheat, barley, chickpeas (the Sumerian-derived word hummus is still used, now for the pulverized form, in many cultures), and possibly other foods. Sheep and goats followed soon after (about gooo years ago). The first domesticated crops so far discovered were in the Syria-Turkey border country. Soon such crops extended down to Palestine and into Iraq and Iran.

It was once naturally assumed at first that people were reduced to farming by lack of other food, possibly because of the die-off or kill-off of the Pleistocene megafauna. But Carl Sauer pointed out long ago ${ }^{4}$ that this could not be the case. The Chinese say: "when you're thirsty it's too late to dig a well." Domestication is a slow, difficult, chancy process, and if people were hungry, they would move rather than sit and wait a thousand years for domestication to succeed.

In fact, in the Near East, the end of the Ice Age did not mean the death of vast herds of megafauna. There were none there, merely a few elephants and

4 Sauer (1952), Agricultural Origins and Dispersals. 
such. The end of the Ice Age there and in China did result in other changes, including the return of warmer, wetter conditions, and thus of lush plant life. Domestication took place during a time of improving conditions.

Domestication took place not in a time of tiny bands of starving hunters and gatherers, but in a time and place of large, well-off settlements. The black volcanic hill of Karacha Dag in south Turkey was an early site of domestication of wheat and chickpeas, and within a day's walk was the great town - almost a city—of Göbekli Tepe, with monumental architecture, large buildings, extensive streets and apparently a comfortable life, just before agriculture developed. It has evidence of feasts, but not of ordinary meals - it may have been a purely ceremonial site. Large towns also existed in Palestine and Syria.

The theories that agriculture developed due to hunger must be abandoned. ${ }^{5}$ Its beginnings certainly had a great deal to do with trade and exchange, ${ }^{6}$ probably with farmers exchanging crops with hunters for meat, and later for dairy products. Agriculture also developed at least in part to provide more convenient, close-at-hand, reliable food for large towns - a theory proposed long ago by Jane Jacobs, ${ }^{7}$ and treated with ridicule, but now apparently verified in the Göbekli Tepe case.

It may, also, have developed in part to provide more food and drink (wine became quickly important ${ }^{8}$ ) for feasting, as Brian Hayden thought. ${ }^{9}$ Feasts in early societies (as they are still today in the Middle East and in the Eurasian heartland) were part of a way of life, and were a most important political as well a social ritual; it was not simply about eating. They were the ways people cemented alliances, made, and closed deals, repaid loyalty and friendship, and, above all, attracted and kept followers. Marco Polo records the great feasts of Qubilai-qan's China involving tens of thousands. These were mirrored in other parts of the Mongol world, for example in the Ilqanate, where our pictorial sources often illustrate feasting and connected social activity.

A local leader who could not be generous was abandoned by his supporters and became easy prey for a more generous leader. Conspicuous consumption in which everyone ate and drank well was part of politics. Throughout the Eurasian heartland and recorded history, feasting and generosity have been as important to conquest as swords and arrows. A leader who cannot reward his

5 Anderson (2014), Caring for Place; for a review of theories see Barker (2006), The Agricultural Revolution in Prehistory.

6 MacNeish (1991), The Origins of Agriculture and Settled Life; MacNeish (1977), "The Beginnings of Agriculture in Central Peru," 753-801.

7 Jacobs (1969), The Economy of Cities.

8 Fragner, Kauz, and Schwarz (2014), Wine Culture in Iran and Beyond.

9 Hayden (2001), Feasts:Archaeological and Ethnological Perspectives on Food, Politics and Power. 
troops, or feast his retainers, is an abandoned leader. In most of Central Asian history that meant a dead leader. Leaders had to keep winning. They had to develop the common economy, survive, and flourish. The dawn and spread of agriculture were influenced by this pattern long before there were pastoralists and Mongols. And Göbekli Tepe may show one stage in the development of this pattern.

In China, agriculture developed some $8000-9000$ years ago. ${ }^{10}$ In China the Pleistocene megafauna continued to exist. China was swarming with elephants, rhinoceroi, deer, buffaloes and other large animals, at the time agriculture began. Early farmers hunted them to supplement their diets. ${ }^{11}$ Most species survived till long after civilization began; the real population crash of China's megafauna is quite recent, largely since the end of the Ming Dynasty. ${ }^{12}$ As in the Near East, agriculture started during a time of warming and wetter conditions, when everything was better for plants, animals and people. And it seems to have taken place among settled people with substantial settlements, as in the Near East, although we are not yet sure.

The early agriculture in western Asia was based on wheat, barley, chickpeas (garbanzos), lentils, and broad beans, all from the "Fertile Crescent" in Syria, and in neighboring countries. With genetic data, we can now pinpoint some plants to exact loci of domestication.

The most important crop in the world today is wheat, specifically bread wheat. Bread wheat is one of the more amazing inventions in history. Here we must pause for some genetics, just to impress the reader with how wonderful wheat is as a grain. The initial wheat was einkorn, a domesticated variety of Triticum urartu. Einkorn has the varietal name of var. monococcum. It is now almost extinct, though still cultivated in a very few places. Wheat taxonomy remains confusing; late research shows urartu as the parent. The parent was not boeoticum as formerly thought. Einkorn was the one domesticated at or near Karacha Dag.

10 Anderson (2014), Food and Environment in Early and Medieval China.

11 Yunfei, Crawford, and Chen, "Archaeological Evidence for Peach Cultivation and Domestication in China," PLoSOne Dor:10.1371/journal.pone.o106595 (2014).

12 Wan, et al., "Historical Records Reveal the Distinctive Associations of Human Disturbance and Extreme Climate Change with Local Extinction of Mammals," Proceedings of the National Academy of Sciences 116 (2019), 19001-19008. 
Not too far away, emmer, a product of probably natural hybridization, was domesticated. It is a cross of T. urartu with Aegilops speltoides, a wild wheatlike grass. (Emmer has its own name: T. turgidum var. dicoccum, with a var dicoccoides sometimes recognized for wild emmer). Emmer is still an important crop in Italy, under the name of farro, and in some other areas. Its hard-grained descendant durum wheat is the source of Italian pasta.

Then, somewhere in northwest Iran or just north of it, this plant crossed with another grass, Aegilops tauschii. The result was a wheat with a superior gluten, one that trapped bubbles of carbon dioxide when the bread was leavened, and thus allowed the fluffy, aerated loaves the world now knows so well. We like to think that a woman noticed the superior quality of bread she was making and traced it to odd-looking wheat growing in one corner of her fields. Thus was launched bread wheat-a three-way, hexaploid hybrid- now perhaps the most widely grown grain in the world. Wheat, maize and rice all vie for prominence. They are so close, in production totals, as to be within statistical-error distance of each other, so it is hard to say which one is dominant. Wheat is the most versatile and the most widely eaten.

Barley (Hordeum vulgare) has a less hybridized, but no less complex, origin, involving still-unclear mixing, selecting, and propagating. At least we now know it too comes from the Fertile Crescent. ${ }^{13}$

The Eurasian heartland owes most of its domesticated plants to the Near East, from the staple foods, wheat and barley, and to important but lesser crops including almonds, melons, sesame, cumin, and coriander. The region itself contributed apples and possibly apricots. Spinach and alfalfa were domesticated early, somewhere in the Iranian region (spinach was introduced to China from Nepal as well as Central Asia, still known as the "Persian vegetable"). Carrots, often attributed to Afghanistan, are probably Near Eastern, but we are not certain. The all-important grape is native to the Caucasus and east Black Sea region, whence it spread by 8000 years ago. China has its own species of wild grapes, and the earliest evidence to the use of grapes in brewing, to make a kind of fruit-flavored millet ale, is from China, some 70oo years ago. ${ }^{14}$

North China contributed broomcorn millet and foxtail millet. Of these grains, only broomcorn millet was hardy enough to move rapidly into the Eurasian heartland and become widespread there; it reached Europe by somewhere between 1500 and 2000 BCE. It, barley, and wheat remained overwhelmingly dominant among Eurasian heartland grains until early historic (2012), Domestication of Plants in the Old World.

14 Fragner, et al., (2014), Wine Culture in Iran and Beyond. 
times. ${ }^{15}$ Foxtail millet, requiring more moisture and preferring more warmth, stayed in China, but spread to southeast Asia and India quite early; it appears in India by the 2nd millennium BCE. It may have spread through Central Asia, though the earliest evidence of it there is not until the late 1st millennium вСЕ. ${ }^{16}$ Chinese agriculture was long based on two species of millets in the north, and rice and root crops in the south. The millets came in at 7000-80oo $\mathrm{BCE}$, the rice around $600 \mathrm{BCE}$, although there are now claims of much older (but probably undomesticated) rice. Rice was earliest in the lower Yangzi region, but spread north rapidly to Shandong 山東, appearing there by 6000 BCE, though possibly in undomesticated form. ${ }^{17}$ They gradually entered a world incredibly rich in food plants-indeed, China is the most botanically rich area in the temperate zones. Thus, we find amazingly diverse food plant assemblages in the earliest sites that have millets at the time of transition between gathering and agriculture. ${ }^{18}$ Again the origin story does not concern us ${ }^{19}$ except for broomcorn millet.

Broomcorn millet (Panicum miliaceum) is ancient in the Eurasian heartland. More resistant to drought and dry continental climates than other grains, it became a life support, vitally important in the first millennium в $\mathrm{CE}$, at which time it grew along with wheat, barley, cotton, sesame, melons, grapes and other fruit. ${ }^{20}$ It continued to be important until modern times. Being neither very tasty nor very versatile (it is good for porridge but not much else), it has been low in status, and thus replaced by wheat and imported rice as economic growth made those more available. It had reached western Central Asia by 2700 BCE, when it shows up as animal forage in Kazakhstan. ${ }^{21}$ Presumably people were also eating it. It reached Europe soon after. It spread fairly rapidly into dry northwest China, but once in the hard desert it had to wait for

15 Mair and Hickman (2014), Reconfiguring the Silk Road.

16 Stevens, Murphy, Roberts, et al., "Between China and Southeast Asia: A Middle Asian Corridor of Crop Dispersal and Agricultural Innovation in the Bronze Age," The Holocene 26 (2016), 1541-1555. Yuezhuang Site in Shandong Province, China," The Holocene 26 (2016), 1594-16o4. Li and Chen (2012), The Archaeology of China: From the Paleolithic to the Early Bronze Age; Wu, Wang, Wu, et al." The Early Holocene Archaeobotanical Record from the Zhangmatun Site Situated at the Northern Edge of the Shandong Highlands, China," Quarternary International 348 (2014), 183-193; Hunt, Rudzinski, Jiang, et al, „Genetic Evidence for a Western Chinese Origin of Broomcorn Millet (Panicum miliaceum)," The Holocene 28 (2018), 1968-1978.

21 Kiel University (2019), "Earliest Spread of Millet Agriculture Outside China Linked to Herding Livestock," PhysOrg, Sept. 6. 
intensive irrigation to make it worth growing. It is not competitive in quality with wheat or barley, and thus waited until irrigation was well developed enough to provide considerable land for growing low-value crops. Given that, and also a moister phase in western Central Asia, it crossed the Altai in the 3 rd millennium вСE. It is first attested as a major food at Begram, Kazakhstan, around 2200 вСЕ. ${ }^{22}$ Following that date it spread widely in Central Asia, but lost ground in China, as rice became more common.

In the early Middle Ages, sorghum entered the area from Iran and Indiaultimately from Africa, where it is native. Sorghum, plus improved wheat agriculture, reduced millet to minor status in some areas. Both millets and sorghum are $\mathrm{C}_{4}$ plants. $\mathrm{C}_{4}$ plants use a carbon metabolism pathway that makes them more resistant to heat and drought than $\mathrm{C}_{3}$ plants such as wheat and barley. They also leave a characteristic signature in the bones of the eaters, so we can tell when millet became a staple.

Rice, another East Asian domesticate, and a $\mathrm{C}_{3}$ plant, became important much later, especially in the river valleys of Afghanistan and in the Caspian Sea drainage; it probably came via India (where it was apparently domesticated independently of the early Chinese domestication) and Iran rather than directly from China. It probably appeared there about the same time it did in Iran: some 2000 years ago. It is now a major crop in Iran, but in dry Central Asia it is important only in the river valleys of Kazakhstan and Uzbekistan. Koreans resettled there had a good deal to do with its rise to importance in the former. ${ }^{23}$ China also contributed several minor species, including the peach, domesticated in the lower Yangzi Valley around 5000-7000 years ago. ${ }^{24}$

The major period of spread in Central Asia of the four big starch stapleswheat, barley, millet and rice - was thus around 7000 to 4000 years ago. Wheat, barley, and millet, along with peas, formed a complex that migrated northward between 2000 and 1000 BCE, moving downward into deserts and northward into Mongolian and Siberian steppes. ${ }^{25}$ This means diffusion was at about the

22 Liu, Reid, Lightfoot, et al., "Radical Change and Dietary Conservatism: Mixing Model Estimates of Human Diets along the Inner Asia and China's Mountain Corridors," The Holocene 26 (2016), 1556-1565; Miller, Spengler, and Frachetti, "Millet Cultivation across Eurasia: Origins, Spread, and the Influence of Seasonal Climate," The Holoocene 26 (2016), 1566-1575.

23 Nesbitt, Simpson, and Svanberg (2010), "History of Rice in Western and Central Asia,"308340, 535-541.

24 Zheng et al. (2014), "Archaeological Evidence for Peach Cultivation and Domestication in China."

25 Miller, Spengler and Frachetti (2016); Spencer, Ryabogina,Tarasov, and Wagner, "The Spread of Agriculture into Northern Central Asia: Timing, Pathways, and Environmental Feedbacks," The Holocene 26 (2016), 1527-1540. 
same rate as in Europe, where agriculture took about 4000 years to get from western Turkey to England (around 8000-900o to 4000-500o years ago). Based on parallels with modern diffusion of starch staple crops, the diffusers were surely ordinary people, and very possibly the poorer and more marginal ones. They were the ones under the most pressure to find a good cheap source of livelihood. Grains are easy to grow and store, unlike the meat and fresh plant foods beloved by the elites.

In later (early-Medieval) centuries, important crops have come to the region, and ultimately to East Asia from Africa: sorghum and watermelons. Both were introduced in, or shortly before Liao 遼 times. India contributed mung beans, many spices including turmeric, and cardamom, major rice varieties, and many other crops. In the last very few centuries, the New World has provided potatoes, tomatoes, squash and common beans. Sorghum has not only been important as a food plant but has long provided one of China's most important distilled liquors, gaoliang 高粱. (The other favorite, maotai 茅台, is made from millet. Distilled liquor in general is often called sanshao 三 燒, "triple distilled," even if not actually distilled that many times.) No gaoliang is found in the Eurasian heartland, but other distillates certainly are. The Mongol era was a particularly important period of dissemination both for distilled liquors and for the stills used to produce them as noted above.

The Eurasian heartland itself made at least two major contributions to the world. Horses and apples (Pyrus malus) are the clearest cases. They have been nailed down by genetics to an origin in Kazakhstan. Horses were domesticated in the Kazakh steppes. Apples come from mountains near the city now called Almaty, "Father of Apples." Almaty, Tashkent, and Kabul markets are full of tasty, mostly dried but often fresh, fruits of every kind. This is, somewhat unexpectedly, also the case in Ulaanbaatar's public markets. Most is imported from China.

Very early and important in the region were several other fruits. Above all grapes (Vitis vinifera). Pistachios from Iran, almonds from what is now Turkey (with possible inputs from other areas), and melons, and pomegranates from the ancient Near East have long been important. Sesame (Sesamum indicum) possibly came from India originally, but arrived early. It certainly reached Central Asia via the ancient Near East. ${ }^{26}$ Sesame became an important oil crop, tolerating dry conditions. It yields poorly, even with modern breeding efforts, and thus animal fats have prevailed throughout history in high Asia.

26 Bedigian (2013), "African Origins of Sesame Cultivation in the Americas," In African Ethnobotany in the Americas, 67-12. 


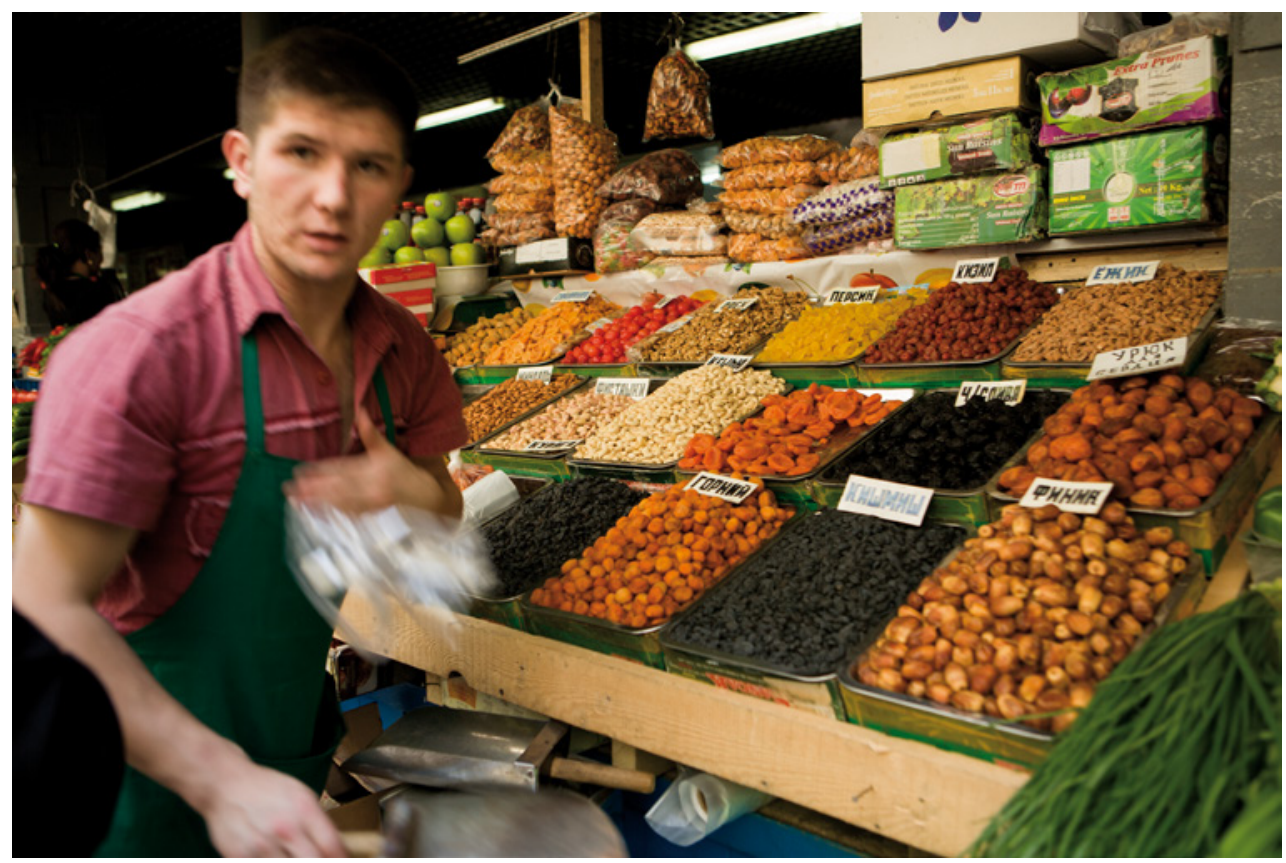

Рното 20 The public market in Almaty

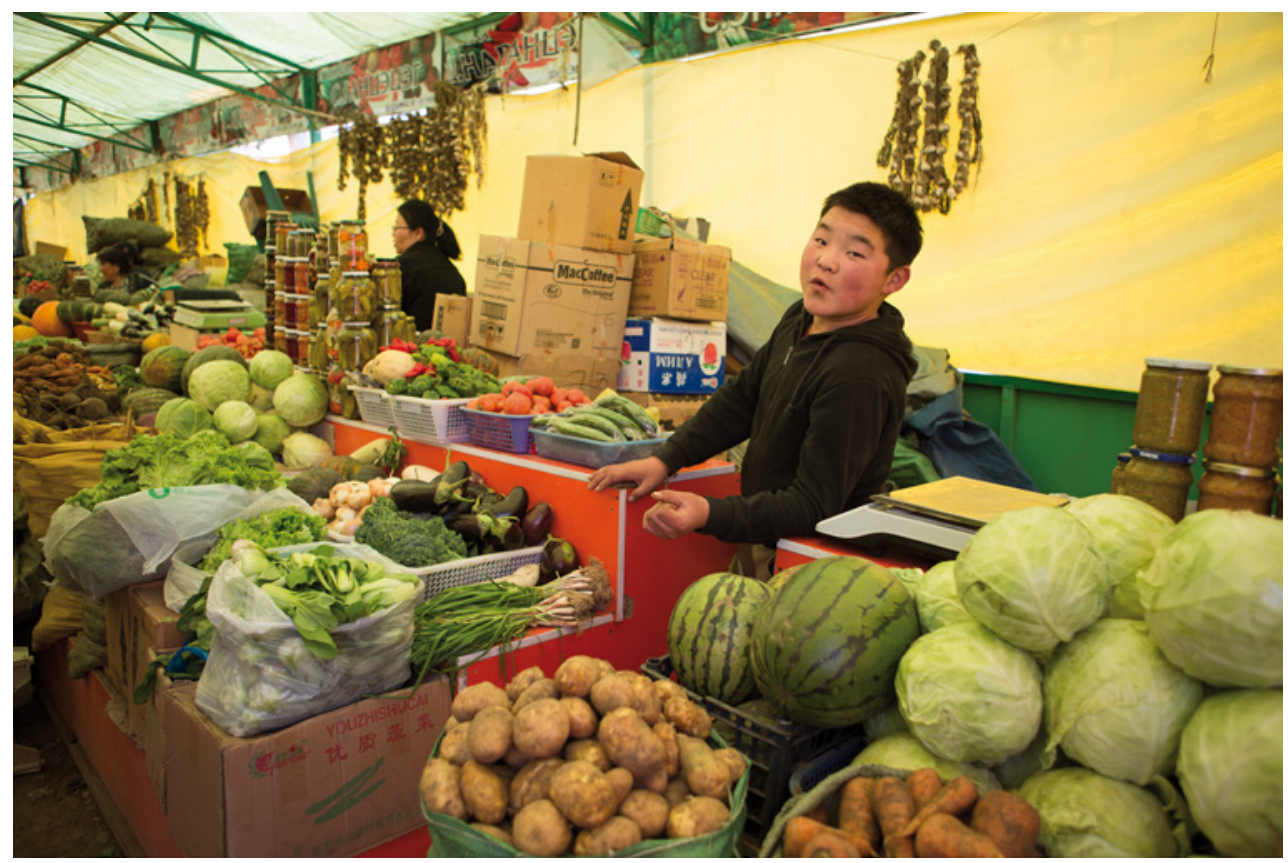

Рното 21 A public market in Ulaanbaatar 
Finally, even in early times, cotton (Gossypium herbaceum) was an important fibre plant. The ancient cotton came from Arabia and India. It was shortstaple and low-yielding. Early Europeans heard stories of Indian "plants that bore wool." They concocted the story of the "vegetable lamb," a plant with little sheep growing on it and grazing around it; this remained a staple of travelers' tales even after cotton was well known. The superior cotton grown today in the region is a Native American development (G. herbaceum, G. barbadense), coming from the pre-Columbian Caribbean, not reaching the Eurasian heartland until the 19th century. (Cotton is only one of many plants in which different species of the same genus were independently domesticated in the Old and New Worlds.) The Civil War in the United States made it suddenly a major Old World crop, as American supplies were embargoed. ${ }^{27}$

At an uncertain, still quite early time, outside spices and flavorings began to come into the Eurasian heartland. The region already had some of its own: various species of thyme, wormwood, and umbelliferous plants. Probably among the first Near Eastern spices to come were cumin (Cuminum cyminum) and coriander (Coriandrum sativum), the classic spices of the Near East, whose domestication and use go back many thousand years. Coriander is used for its leaves as well as for its dry fruits, or "seeds," ground as spice. Thyme, black caraway (Nigella), marjoram, and other herbs and spices followed. Black pepper (Piper nigrum) has probably been in the Eurasian heartland for at least 2000 years, judging from its early use in China; cinnamon, clove and other Southeast Asian spices may also be early. The classic Near Eastern and Turkistanian spice mix today is cumin, coriander and black pepper. Other spices are added according to the background and sophistication of the dish being cooked.

Gathering of wild plants has remained important in Central Asia. CinggisQan's vicissitudes with cinquefoil roots and other gathered foods and simple game are well-known. A recent study of lily bulbs in Russian history shows that all ethnic groups have used any lilies and fritillaries that provided edible bulbs or corms. ${ }^{28}$ Wild greens, fruits, berries, and roots have always been popular.

27 Rosenberger (2012), Seeking Food Rights, 29.

28 Ståhlberg and Svanberg (2014), "Among Fishermen and Horse Nomads: Johan Peter Falck in Russia and Siberia 1768-1774," 73-99. 


\section{Domestic Animals}

Domestication leads to more tranquil animals. ${ }^{29}$ Over time, that may mean stupider animals. ${ }^{30}$ The wolf (Canis lupus) averages about $100 \mathrm{cc}$ of brain, while the $\operatorname{dog}$ (a domesticated wolf, C. lupus var. familiaris) 72 cc. Pigs (Sus scrofa) have lost $1 / 3$ of their brain mass; wild pigs are notoriously savage and cunning - traits intolerable in a domesticated pig. Cattle, sheep and goats have suffered comparably. Even the mink, domesticated (on fur farms) for only a few decades, has lost $20 \%$ of brain mass. ${ }^{31}$

In a famous study, Dmitri Belyaev, on a fox fur farm in Russia, studied the progressive domestication of the foxes raised there. Over half a century, foxes selected for tameness became not only more docile, but also developed the short muzzle, flop ears and tendency to spotted coloration that distinguish the more "derived" breeds of dog from the wolf. ${ }^{32}$ Similar changes have shown up in sheep, rats, guinea pigs, horses and other domesticates, and are now thought to be due to the fact that docility is developmentally linked with melanin distribution, ear cartilage and so on, in the developing neural crest. ${ }^{33}$ Early farmers took advantage of sophisticated knowledge of animal breeding to develop good animal food sources.

Animal domestication probably began in Eurasia with the dog at some debatable time in the past; the genetical and archaeological evidence is conflicting. The dog was domesticated from the wolf by 14,000-15,00o years ago, ${ }^{34}$ but many think it was domesticated much earlier. ${ }^{35}$ It was apparently domesticated as pet and as a helper in the hunt. Wolf packs easily learn to cooperate with ravens, to follow bears and otherwise to hunt in association with other species. Hunting with humans could have led to cooperation ${ }^{36}$ and the eventual capture of pups, or making pets of orphaned ones, and breeding them for domesticness. All of this is speculative.

29 Clutton-Brock (2012), Animals as Domesticates: A World View Through History.

3o Marshall, Dobney, Denham, and Capriles, "Evaluating the Roles of Directed Breeding and Gene Flow in Animal Domestication," Proceedings of the National Academy of Sciences 111 (2014), 6153-6158; Dugatkin and Trut (2017), How to Tame a Fox (and Build a Dog).

Zeder, "The Domestication of Animals,"Journal of Anthropological Research 68 (2012), 161190.

Larson, "Genetics and Domestication: Important Questions for New Answers," Current Anthropology 52, Supplement 4 (2011), S485-S495.

33 Gibbons, "How We Tamed Ourselves—and Became Modern," Science 346 (2014), 405-406.

34 Zeder, "The Domestication of Animals."

35 Shipman (2015), The Invaders.

36 Raymond Pierotti (2011), Indigenous Knowledge, Ecology, and Evolutionary Biology. 
The typical Central Asian dog is a mastiff-type herd dog. These dogs do not herd the animals as sheepdogs do; they guard them. They are the eastern forms of a widespread large herd dog. The Swiss and Pyrenees mountain dogs anchor the west end of this continuum. Many are notoriously fierce: the Turkish kangal (Armenian gambr), the beautiful but protective Central Asian sheepdog (the typical Georgian dzaghli), the Alan or "alaunt" dog (brought to Europe by the Alan nomadic tribes of Roman Empire times), and the Tibetan mastiff, being especially famous. Some of these breeds, such as the Turkish akbash and the more traditional type of $d z a g h l i$, look almost exactly like sheep, and mix with the flock, identifying with its members but suddenly emerging to attack mercilessly a wolf or human that approaches. The Mongolian bankhar mastiff, however, is smaller, friendlier, and susceptible of being lured from its strict guard functions by bits of bread, although bankhar will defend their communities if provoked. In Mongolia, the tradition has been that anyone visiting a home or camp must call out to the household to keep the dogs under control, although when we visited Mongolia the dogs needed to be talked to personally rather than controlled. They were clearly in charge and permission had to be asked to enter a yurt. Be that as it may, even Cinggis-qan was once afraid of these dogs. The bankhar is astonishingly similar to the Swiss mountain dog breeds, possibly indicating a survival of an ancient type at the far ends of the mastiff chain. Occasional in Inner Asia, especially to the north and east, are spitz-like dogs, with curly tails and prick ears. These are part of a more northerly chain of breeds extending from Scandinavia to Japan. They can herd animals, including reindeer. Locally, hounds occur, including the famed Afghan hound - which in its native home is an elite hunter, smarter and more independent than the sadly inbred Afghans of American dog shows.

The first animals domesticated for food were sheep (Ovis aries) and goats (Capra hircus). Both were first domesticated in the Near East. Sheep were domesticated by about $8000-9000$ BCE, and goats by about 7000 BCE. ${ }^{37}$ Sheep quickly became the major animal throughout dry Eurasia.

Fat-tailed sheep were bred early in the Near East. The fat-tailed sheep is important in Central Asia, where fat is otherwise hard to find. The tail and rump fat is a common cooking fat. It is also an additive to many dishes. In the modern overweight world, we often forget that fat is an essential nutrient, and that getting enough of it has been a major problem for many people throughout human evolution. The fat-tailed sheep stores it in rump and tail, where connective tissue holds it together, allowing pieces to be grilled without simply melting. Caracol (Karakul) sheep and Angora-type goats came much later;

37 Clutton-Brock, Animals as Domesticates; Zeder, "The Domestication of Animals." 


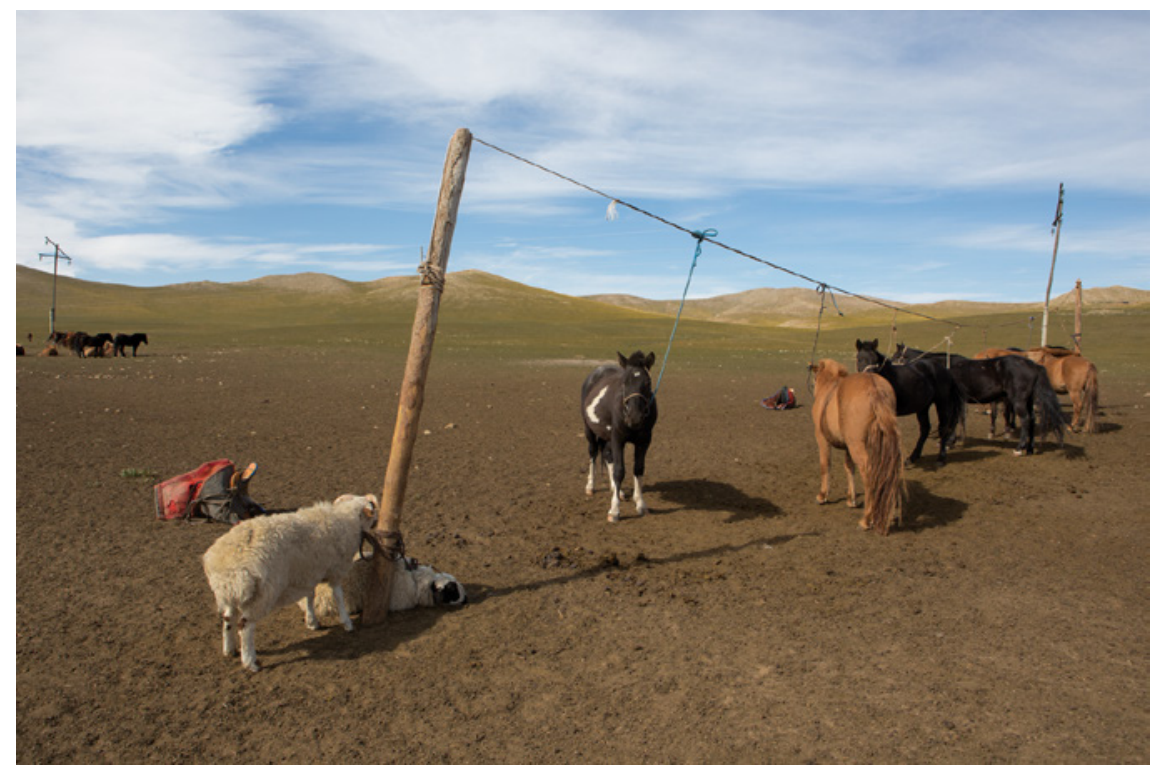

Рното 22 Mongolian fat-tailed sheep

they provided superior wool for all clothing purposes; the Caracol hat is, or was an essential part of men's wear in much of the high Eurasian heartland.

Pigs (Sus scrofa), and cattle (Bos taurus in Europe and Near East, Bos indicus in India) soon followed. All these species had the advantage that they were herd animals. They were not unbearably wild or fast-running. Perhaps more to the point (especially given the savagery of pigs), they were animals that were apt to tame themselves, coming around human camps for food scraps. It has now been established that pigs were independently domesticated, at about the same time (around 8000 years ago), in the Near East and in China. ${ }^{38}$

Similarly, sheep, goats, and cattle came around human camps for salt in wasted food or in urine. Visitors to western North American parks may be aware of how very prevalent is self-taming among wild animals. Mountain sheep and mountain goats in search of handouts are a genuine pest. The Near Eastern species had similar habits. Most modern people do not realize how very different life was before high-powered rifles. Hunted animals have now learned to stay hundreds of yards away from humans. Experience in parks show that animals learn quickly where and when they are safe. In earlier times,

38 Bosse, Frantz, et al., "Genomic Analysis Reveals Selection for Asian Genes in European Pigs Following Human-Mediated Introgression," Nature Communications (2014), doi 10.1038/ncomms5392, 15 July. 
even hunted animals stayed close; they knew how far a bow could shoot accurately, and knew they did not need to run farther than that.

Quite a few promising species were missed. Red deer (Cervus spp.), for instance, have proved excellent farmstock in New Zealand, where they live happily with sheep and cattle, being peacefully herded by border collies. American elk (a form of red deer) eagerly self-tame, and are a familiar and friendly sight in many western American communities. Asian red deer were not domesticated, but probably because other animals were domesticated first. By the time agriculturalists expanded into red deer country, they already had good domesticates, and found the red deer - with its formidable antlers - not worth further effort. Central Asia's red deer are now acutely endangered, unfortunately.

Herbivores were initially domesticated solely for meat, but a "secondary products revolution" soon took place as milking, and an associated large-scale cheese-making, arose. Dairying arose early: by 6000 BCE in Anatolia, 5000 in Eastern Europe, ${ }^{39} 3000$ in the steppes, $800-1200$ in Mongolia (the Deer StoneKhirigsuur complex). Skins and bones were also useful, and eventually people managed to develop wool — not a natural product of sheep, but one created by selective breeding, probably between about 5000-3000 вСЕ. Not only sheep, but also goats and other species, became woolly. Bactrian camels (Camelus bactrianus) and yaks (Bos grunniens) naturally produce wool-like coats. The wools produced are particularly important in the Eurasian heartland winters.

All this heightens the interest and importance of the Eurasian heartland's great contribution to world livestock: the horse (Equus caballus; the wild horse is E. ferus, Przhevalsky's is E. [ferus] przewalskii). Horses were domesticated perhaps as early as $3500-3000$ вСE, probably in Kazakhstan, and possibly neighboring areas of the steppes, as is now shown from archaeological and genetic research. ${ }^{40}$ The Botai culture, at that time, initially depended on hunting wild horses for food. The Botai people apparently domesticated the horse. The process centered in the steppes of Kazakhstan. Horses were apparently domesticated for eating, and only later milked and ridden. Either way they have been critically important food producers, as well as being essential to steppe herding. Horse meat was important throughout history, and continues

39 Clutton-Brock, Animals as Domesticates; Jeong, Wilkin, Amgalantugs, et al., "Bronze Age Population Dynamics and the Rise of Dairy Pastoralism on the Eastern Eurasian Steppe," Proceedings of the National Academy of Sciences 115 (2018), E11248-E11255. Prehistoric Steppe Adaptations and the Horse; Marshall, Dobney, Denham, and Capriles, "Evaluating the Roles of Directed Breeding and Gene Flow in Animal Domestication," Proceedings of the National Academy of Sciences 111 (2014), 6153-6158; Zeder,"The Domestication of Animals." Donkeys, native to North Africa, had long been domesticated there. 
to be a major food in Kazakhstan, ${ }^{41}$ where it is served as fatty as possible. It is also of growing importance in Mongolia, where horses were once too valuable to eat.

Horses seem, however, to have drawn on a steppe-wide gene pool, from the Ukraine to the Altai. The Przhevalsky Horse is a descendent of feral Botai horses, not a truly wild animal; other domestic horses have absorbed genes from many other now-vanished wild populations. ${ }^{42}$ They were later milked on a rapidly increasing scale. In season, horses produce a substantial supply of milk, and Mongols are awash in fermented mare's milk during the summer. Only much later were they used for draught (including pulling chariots) and for riding. The Botai culture has left pots containing residue of mare's milk. This shows domestication; milking wild horses is impossible. One could not approach them, and if one could the mare would be defensive of herself and her foal; an enraged horse can and will kill a human. One can only stand in awe of the women who first milked horses in Kazakhstan; it must have followed a considerable period of breeding for docility. ${ }^{43}$

Horses were at first an unpromising animal to domesticate, because they are formidably intelligent, and before domestication they were extremely wild and independent. The other herbivorous domesticates are largely ruminant: sheep, goat, cow, and camel. A ruminant animal is basically a walking fermentation tank. It does not have to think much, and thinking interferes with digestion. Horses are different: they do not have the "four stomachs" of the cow. They do not chew the cud. Without the fermentation step to help digest food, horses have to be smart to get enough forage. Horses must be provided quality foods. These are usually leaves or grains of grasses, leaves of leguminous plants, or comparable nutritious fodder. Since horses are needed for riding and work, rather than for meat, humans could not simply breed the brainpower out of them, as they could with sheep and cows.

Wild equines do not take kindly to being managed, and they resist annoyances with a combination of intelligence and toughness. Anyone who has watched zebras deal with lions knows this. The surviving wild horses-the Przhevalsky's horses of the eastern steppes-appear equally resourceful. Today, the better breeds of horse have been bred to combine high intelligence

41 Levine, "Eating Horses: the Evolutionary Significance of Hippophagy," Antiquity 72 (1998), 90-100.

42 Achilli, Olivieri, Soares, et al., "Mitochondrial Genomes from Modern Horses Reveal the Major Haplogroups that Underwent Domestication," Proceedings of the National Academy of Sciences 109 (2012), 1449-1454; Gaunitz, "Ancient Genomes Revisit the Ancestry of Domestic and Przewalski's Horses," Science 36o (2018), 111-114. 


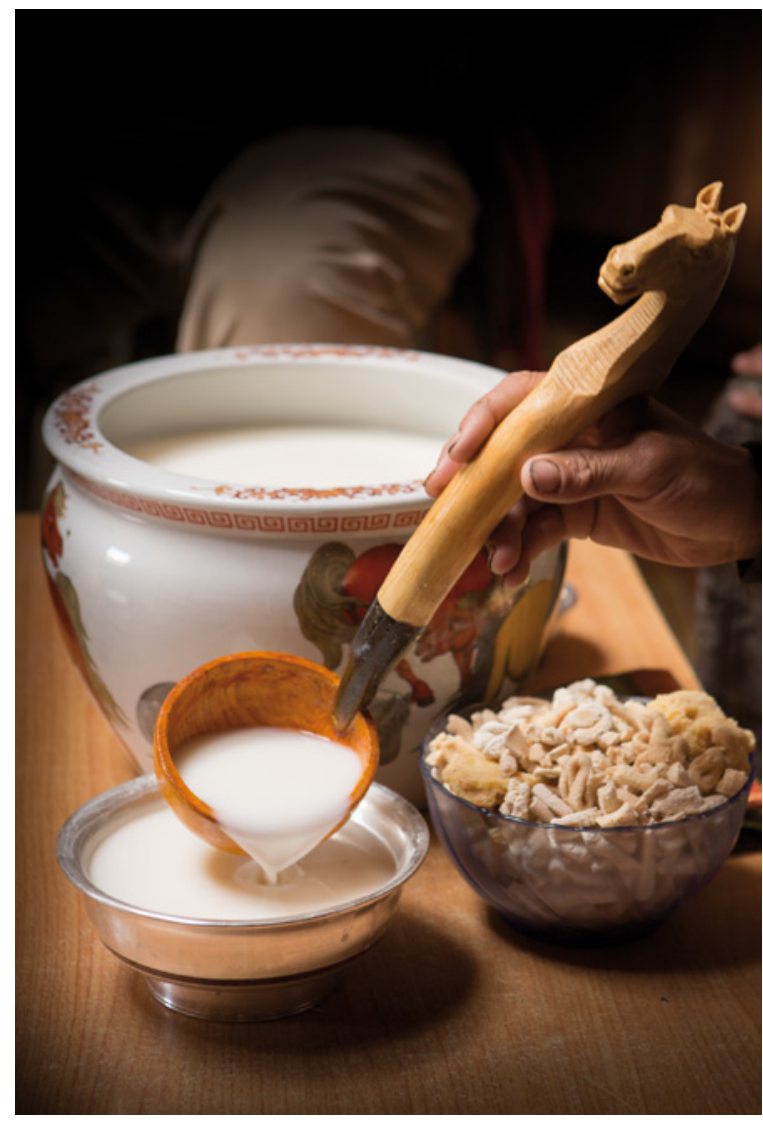

Pното 23

Fermented mare's milk prepared for a guest

with doglike devotion and trainability. This was a truly amazing accomplishment, and it was the move that really opened the steppes. In recognition of this, Mongolian folklore has a hierarchy of intelligence: heroes are portrayed as - to coin a phrase - kind of dumb, girlfriends are smarter, but if both get into a jam, it is the horse who bails them out. The older, "warmer" breeds in particular have a formidable intelligence and stunningly sharp senses. Many an ordinary rider in modern times has had to depend, like an epic hero, on an intelligent mount, whether the need is for sure-footedness on a mountain trail, finding the way in a blizzard, or sensing danger from human, predator, or poisonous snake.

The human-horse symbiosis is ancient and deep-rooted, and allowed the conquests by the Mongols, and the peaceful occupation of remote steppes. Horses were probably used relatively early for pulling carts, then much later for chariots, and still later as riding animals. Early finds once thought to be 
evidence of riding have proven not to be, ${ }^{44}$ leaving us in the dark about that vitally important innovation. Similarly, exorbitant claims of early Indo-Europeanists have not panned out. There were no vast mounted hordes sweeping out from the Ukraine carrying Indo-European languages with them. If the languages spread as claimed, a slower and more gradual mechanism was at work.

The other large animal domesticated in Central Asia was the Bactrian camel, native to the deserts of the eastern part of the region. A few wild ones survive in southern Mongolia. Presumably, the Arabian dromedary (Camelus dromedarius) was first domesticated (by $2000 \mathrm{BCE}$ ), and later introduced to Inner Asia, where it flourishes in the warmer southerly regions such as Afghanistan, and at one time as far north as southern Mongolia. Lacking evidence, we can surmise that northward expansion of economic activity would have naturally led people to substitute the more cold-tolerant Bactrian. Nonetheless, it seems to have been domesticated early. ${ }^{45}$ It too provides meat and milk.

A modern nomadic herder will have largely sheep, with a few goats, and the necessary few horses - or more than a few; horses are everywhere in Mongolia and Kazakhstan. In true desert areas, there will be perhaps as many camels. Cattle are uncommon (but increasing in numbers), and donkeys are rare. Yaks are common in mountain and rocky areas only. Pigs are ruled out by Islam in most areas, and in almost all areas by climate, and by the need for mobility. Cattle and pigs abounded in neighboring Europe and China, and expanded into Central Asia, usually at the margins of the region, whenever climate permitted. Sometimes expansion was more broadly-based. In the first millennium $\mathrm{BC}$ and even later, they were kept in the great river valleys of the core regions. ${ }^{46}$ Of course the coming of Islam made pig-keeping inconceivable throughout most of the region. It is perhaps for this reason that the official Mongol-era cookbook and dietary manual, the Yinshan Zhengyao, has few recipes for pork, which would have been offensive to Muslims at the court. Mongol tradition, in which wild pigs were simply not important, may have played a role as well.

Chickens came later from Southeast Asia and South China. One bird that may be a local domesticate is the pigeon. Pigeons descended from wild rock doves (Columba livia), which are still common in the area. The origin of the domesticated pigeon is obscure, but is probably Middle Eastern. In Iran and neighboring areas, including western Afghanistan, ${ }^{47}$ tall adobe towers are

\footnotetext{
44 Kuzmina, The Prehistory of the Silk Road, 30-32.

45 At least so thinks Kuzmina, in the The Prehistory of the Silk Road. See also Baumer (2012), The History of Central Asia, Vol. 1: The Age of the Steppe Warriors.

46 Brite, "The Archaeology of the Aral Sea Crisis," 16o.

47 Dupree, Afghanistan, 142; Anderson, personal observation.
} 
made with niches every foot or two; these are for pigeons. The birds are good eating, but more important is their dung, a major local fertilizer.

\section{Languages}

Along with agriculture, the ancestors of modern languages spread through the Eurasian heartland. Languages are grouped into very large groupings called phyla. The Indo-European (IE) phylum is generally accepted, though it includes languages like Greek, which has a very large non-Indo-European vocabulary. IE speakers evidently mixed with many speakers of unrelated languages long ago. In the case of the "Altaic phylum," which are theoretically the Turkic, Mongol, Tungus and Korean languages, the tendency today among linguists is to deny that such a thing ever existed. ${ }^{48}$ Tungus and Korean are related, but otherwise the branches seem to have borrowed extensively from each other rather than sharing a common root. (Japanese, sometimes claimed to be "Altaic," is either quite unrelated or only very distantly so.) In fact, the linguistic picture in the Eurasian heartland is more complicated than any simple spread of languages, related or unrelated, might imply. Nonetheless, as anyone can testify who has learned local languages of the Eurasian heartland such as Mongolian and Kazakh, there is a clear similarity between them in structures and vocabularies. The speakers of these languages have interacted over the long term and have acquired similar characteristics, through these interactions, leaving aside the question of actual relationship.

Early and local players included the Xiongnu language, now gone almost without trace and thus of unknown relationships. The Xianbei 鮮卑, a group that formed part of the Xiongnu empire, spoke a language distantly related to Mongolian, and closely related to the Khitan language of the Liao 遼 Dynasty (9097-1115); the Khitan were displaced and set up a later empire in eastern Central Asia, thus making their language a part of its history.

More ascertainable are the recent histories and current statuses of the principal languages in the larger region. The western Eurasian heartland is currently dominated by two language families: Turkic (Kazakh, Uzbek, Uighur, etc.) and Iranic (Persian, Tajik, and more distantly, Afghan and its relatives). In the eastern parts, the Mongolian languages and Chinese have become the

48 Alexander Vovin, "The End of the Altaic Controversy: In Memory of Gerhard Doerfer." Central Asiatic Journal 49 (2005), 71-132; Cecil Brown, personal communication to ENA, emails of fall 2017; Dr. Brown has preliminary evidence that the link between Korean and Tungusic may be a genuine relationship. See also Shimunek (2017), Languages of Ancient Southern Mongolia and North China. 
important ones, with Tibeto-Burman languages reaching as far north as Qinghai province.

Throughout the wider area are also languages not readily associatible with this pattern. One such language is Tibetan. It is related to Chinese, but it has strong Mon elements (the Mon-Khmer phylum includes Vietnamese and Cambodian; Tibetan chronicles even mention the presence of Mon languages in Tibet in very ancient times). Thus, Tibetan shows strong Southeast Asian connections that have little or nothing to do with Chinese. Tibetan is also closely related to Burmese, which has its own non-Burmese borrowings (again often Mon) contributing to the mix. In Siberia are many highly interesting groups such as Ket, which may be the last representative of an ancient, widespread phylum. ${ }^{49}$

All these languages of the Eurasian heartland, except Iranic, have moved into the main parts of their Central Asian haunts within historic time. The Turks came down from the Siberian Altai, or that general vicinity, as part of the nomadic confederations of the period around 1700-200o years ago. The Mongols began moving south and west from southern Siberia and northern Mongolia at about the same time. Chinese expansion into Central Asia came also at this time, but did not become a flood until the last half of the 2oth century. In the case of the Turks and Mongols, change has been as much assimilation as it has been the product of migration. Noteworthy are strange languages such as Tuvinian, which combines a Turkic grammar with a largely Mongolian vocabulary. Similar is Manchu (only very marginally Central Asian), which has undergone considerable Mongolization and Sinicization, mainly in vocabulary.

One other language group, once mainstream, but now defunct, was historically important: Tokharian. This was an Indo-European language family. It is not close to Iranic, being perhaps closer to Balto-Slavic. It is now completely extinct. At least three Tokharian languages were being written and presumably spoken in what is now Xinjiang in very early times. They existed there from some indeterminate, but distant, time of origin until about $1000 \mathrm{CE}$. Tokharian was likely spoken more widely in the past, before the (apparent) radiation northeastward of the Indo-Iranian languages. ${ }^{50}$ In the early Middle Ages, the Tokharians were gradually assimilated by Turkic peoples, especially the group(s) now known as Uighurs.

Apparently, the Eurasian heartland was largely Indo-European-speaking in Bronze and Iron Age times. It is now widely thought that the Indo-European languages spread from Ukraine and nearby areas around 3500 вСE (give or

49 Vajda 2001), Yeniseian Peoples and Languages; Vajda (2004), Ket.

$5^{\circ} \quad$ Renfrew (2014), "Foreword: The Silk Road Before Silk," xi-xiii. 
take a bit), in connection with the development of horse domestication. ${ }^{51}$ This is many years too early for chariots and horse riding, though carts - probably pulled mostly by cattle-were known. ${ }^{52}$ Horses were meat at such a remote date. The spread to Central Asia, however, was appreciably later, with riding and carts likely involved. This spread is conjecturally dated around 2000-1500 BCE.

In recent times, Turkic has supplanted Tokharian completely, and has replaced Iranic languages over a wide area of Inner Asia. It is divided into three branches geographically: eastern, including Uighur in Xinjiang; central, including Uzbek, Kazakh and related dialects; and western, Turkish and Azeri. (Note that we use "Turkic" for the language family in general, especially its Central Asian branches, and "Turkish" for the modern language of Turkey.) The Turks conquered what is now Turkey between the 11th and 15th centuries, and have slowly achieved linguistic hegemony in an area where Greek, Armenian, and Georgian languages formerly dominated. Modern Turkish has picked up a series of loanwords reflecting its history: from Iranic languages in Central Asia, then Persian, Arabic, Greek and Armenian as it moved into Turkey. More recently have come French borrowings in the late 19th and early 2oth centuries, and English in the 2oth.

Meanwhile, the Chinese pressed west into Inner Mongolia and Xinjiang, where since 1960 they have become by far the dominant group numerically. The Mongols of Inner Mongolia, and the Xinjiang Turkic peoples (the Uighurs and their relatives), are now minorities in their own lands. Russian, meanwhile, once waxed strong against the Kazakh Turkic group in the northern and central parts of Kazakhstan. Since independence, the situation has reversed itself, and perhaps two-thirds of the present Kazakhstan population speak Kazakh. This is in part because many Russians went home after independence, but also because of a high Kazakh birthrate. Russian remains the major way of communicating with the outside world in urban Kazakhstan and Uzbekistan, but this is changing, as both English and the local languages become more widely used.

The principal modern form of Iranic is Farsi, the dialect of Persian native to Fars province in southwest Iran. It is characterized by a very high number of Arabic borrowings, especially for religion and elite culture. This also extends to food—everything from sharbat "drink" to qaliya "fried."

\footnotetext{
$51 \quad$ Anthony (2007), The Horse, the Wheel and Language; Mallory (2014), "Indo-European Dispersals and the Eurasian Steppe"; Mallory (1991), In Search of the Indo-Europeans. 
Widely in Inner Asia, especially Afghanistan, people speak-usually as a second language or "lingua franca" — a closely related dialect known as Dari. The word "Dari" comes from Arabic dar "gate," which by extension means rulers' court (and gallows). Dari was the language of rulers, government and administration in the old days; this persists to some extent. The fact that it was a lingua franca throughout southwestern Central Asia shows the extent and reality of Persian influence; its use coincides with the heavy Persian dominance of foodways.

A quite different branch of the Iranic family give us Pashtun/Afghan and related languages of Afghanistan and Pakistan. Yet another branch, Sogdian, was once the dominant language of the great oasis cities, but now it (or a descendant) endures only in one or two mountain villages.

Today, cities in Turkistan show a mix of languages. Particularly important to realize is the great historic depth of the mix of Turkic and Iranic that characterized, and to some extent still characterizes, the great central cities of Samarkand, Bukhara, Tashkent, and others in that general area. Most individuals were bilingual, many were mixed, and many did not know or care whether they were Tajik, Turk, or both, ancestrally. ${ }^{53}$ The same situation exists today in regard to Russian; it is still the main language of international trade and commerce, and of much of governance, in the ex-USSR cities, and in parts of the countryside. Educated people are often bilingual (especially if from Turkic backgrounds) and increasingly often trilingual, with English as third language.

Under the USSR, linguistic Stalinism required standardizing languages and resettling people — basically, "ethnic cleansing" — and boundary-drawing that was, to put it mildly, creative. Boundaries today are convoluted and irregular, there are, for example, detached pieces of Tajikistan scattered in Kyrgyzstan. Peace and prosperity may be hard to achieve with such complex divisions. It was a deliberate divide-and-rule strategy in intent and effect. How much it was also a genuine belief in "nationhood" remains to be determined.

Today, nationalism is strong. ${ }^{54}$ Afghanistan has its own powerful ethnic tensions. Language politics in Xinjiang and Inner Mongolia are part of a wider attempt by the Han majority to crush the minorities, and eliminate resistance to Han supremacy, preferably by cultural absorption or simply swamping them in ever-growing masses of Han. The same is true in Tibet.

53 Rosenberger, Seeking Food Rights; Rosenberger, "Patriotic Appetites and Gnawing Hungers: Food and the Paradox of Nation-Building in Uzbekistan," Ethnos 72 (2007), 339360 ; for memorable accounts of languages and cultures in the region, see Levin (2006), Where Rivers and Mountains Sing; Levin (1996), The Hundred Thousand Fools of God.

54 Rosenberger, Seeking Food Rights; Rosenberger, "Patriotic Appetites and Gnawing Hungers." 
Finally, a word about "race." Nowhere is the concept of biological "race" more obviously silly than in Central Asia. As the meeting ground of the entire Old World, it shows a complete mixing and merging of all the physical types of Eurasia: blond, blue-eyed people (especially in the northwest) to black-haired, brown-eyed individuals with pronounced eyefolds and flat noses. There are also dark-skinned, prominent-nosed individuals who would not seem out of place in Arabia or India. There are groups that do not really look close to anyone else on earth. Genetic typing shows the mix is real; people have come from all over Eurasia, have merged, and have developed some unique local strains. The wonderful photographs by Peter Yung ${ }^{55}$ of the bazaars in far western China show this perfectly. One sees the same variety in the markets of Afghanistan and Kazakhstan.

Archaeology shows a mixture of human types over 30,000 years ago with both modern and extinct subspecies of humans. There followed a settlement of northern Eurasia by people including ancestral Uralic and other language groups; an expansion across the steppes by people including ancestral IndoEuropeans (at some point), Turkic groups, and evidently many others; and more recent migration, largely in the last 5000 years or somewhat more, from Iran and the Indian subcontinent, creating a very loose latitudinal striation that was constantly varied by migrations..$^{56}$ and a mixture of modern types by 3,ooo years ago, with the present mix of European-looking, East-Asian-looking and intermediate people already distinctly visible in eastern Central Asian archaeological finds. ${ }^{57}$

\section{The Origins of Civilization and High Culture in the Eurasian Heartland}

Agriculture is thought to have spread out to the Eurasian heartland (including Iran) by 6000 вСE, but only Turkmenistan reports dates that early. ${ }^{58}$ Wheat was in Pakistan almost as early, by 5500, and in the southern Caucasus by about 6000.59

$55 \quad$ Yung (1997), Bazaars of Chinese Turkestan: Life and Trade along the Old Silk Road.

$5^{6}$ Jeong, Balanovsky, and Krause, "The Genetic History of Admixture across Inner Eurasia," Nature Ecology \& Evolution 3 (2019), 966-976.

57 Anderson, Food and Environment in Early and Medieval China.

$5^{8}$ Betts, Jia, and Dodson, "The Origin of Wheat in China and Possible Pathways for Its Introduction: A Review," Quarternary International 348 (2014), 158-168.

59 Ventresca Miller and Makarewicz, "Intensification in Pastoralist Cereal Use Coincides with the Expansion of Trans-Regional Networks in the Eurasian Steppe," Nature Scientific Reports 9 (2019), article 8363 . 
The Dniester River was a barrier to the spread of farming spread until 5200 BCE. After that time there was a rapid advance of farming. Farming reached Khvalynsk, on the mid-Volga, by 4700-3900 вCE. This is shown by a find of 158 human burials with sacrificed livestock, including many sheep. ${ }^{60}$ Wheat, barley, sheep, and goats reached Afghanistan and the rest of the western side of the mountain core by $3000 \mathrm{BCE}$, but cereals were not important until after 2000. Wheat and barley got to eastern Kazakhstan by 2500 вCE, but did not become immediately important. ${ }^{61}$ They did not reach China till just before $2000 \mathrm{BCE}$, and then only in the west. This means their spread of farming in East Asia went on at the same rate as the spread of agriculture across Europe. There it advanced about $1 \mathrm{~km}$ per year, from invention around 8500-9500 BCE, later reaching the farthest points in the British Isles around 5000 вСЕ. The speed across Central Asia was comparable, with the Near Eastern cultigens taking 7000 years to go about $6000 \mathrm{~km}$ - slowed down, no doubt, by the mountains and deserts. In the meantime, broomcorn millet spread from China, not reaching central Asia until the 2nd century вСЕ but then spreading fast; the slow initial spread and then rapid spread after 2500 of cereals in Central Asia tracks the change from local networks to the wide-flung trade, interaction, and ceremonial and artistic sharing of the Bronze Age, with the Iron Age providing still greater pressure for agriculture. ${ }^{62}$

Farming was not the only thing that spread. The first copper smelting known is from Tal-i-Iblis, southeast Iran, and dated to 5 Oо० вСE. ${ }^{63}$ Copper smelting occurs about the same time at Belovode in Serbia. The lost-wax method was discovered before 4000 BCE. By 4500 BCE, much copper and gold, as well as other fine goods, appear in tombs of chieftains. ${ }^{64}$ In fact, according to archaeologist Barry Cunliffe ${ }^{65}$ the Eurasian heartland was quite innovative in metallurgy. This had obvious relationships with feasting, and less direct ones with hunting; metal also made more mobile nomadizing possible.

Adult-age lactose tolerance-persistence throughout life of the enzyme that in children breaks down lactose into glucose and galactose-spread rapidly in the western steppes between $4600-2800$ вСЕ. ${ }^{66}$ This means fresh milk could become a major food. ${ }^{67}$ Oddly, lactose tolerance (after about age six to

6o Barry Cunliffe, By Steppe, Desert, and Ocean, 6o-61.

$61 \quad$ Ventresca Miller and Makarewicz, "Intensification in Pastoralist Cereal Use Coincides with the Expansion of Trans-Regional Networks in the Eurasian Steppe."

62 Ventresca Miller and Makarewicz, "Intensification in Pastoralist Cereal Use Coincides with the Expansion of Trans-Regional Networks in the Eurasian Steppe."

63 Cunliffe, By Steppe, Desert, and Ocean, 104.

64 Cunliffe, By Steppe, Desert, and Ocean, 106.

65 Cunliffe, By Steppe, Desert, and Ocean, 104-131.

66 Cunliffe, By Steppe, Desert, and Ocean, 73.

67 Cunliffe, By Steppe, Desert, and Ocean, 73. 
ten) never spread east; it stops almost short in the dead center of Eurasia. Beyond there, most adults must consume most of their milk processed into kumiz, curd, cheese or some other product. Mongolia reveals a small but significant percentage of lactose-tolerant adults; China has very few. Probably, lactic-acid fermentation was so universal and so essential to steppe life by 280 о ВСE that there was no selection pressure for lactose tolerance.

The earliest woolly sheep may have appeared about that time as well. ${ }^{68} \mathrm{At}$ Botai in Kazakhstan, 99.9\% of bones were horse bones, indicating true dependence on horse meat. ${ }^{69}$ This was at 3700-300о в Ве. Horse milk lipid residue was found in pots almost as early. Cunliffe thinks riding was established by this time, ${ }^{70}$ but most experts think it was later.

Four-wheeled wagons appeared in the Yamnaya culture around 3500 BC. Within three hundred years, they had spread all over Eastern Europe and as far as Mesopotamia. ${ }^{71}$ There were many buried wagons by 2200 вСЕ. ${ }^{72}$ The world's first chariots, as well as early copper mining, appear in the Sintasha culture, 2100-175 в вС. ${ }^{73}$ They abounded in China by 15 оо вС.

By 2500 BCE there were large towns in the western Eurasian heartland. ${ }^{74}$ Wheat, millet and livestock provided the food. A major cooling, drying trend around 2200-2000 BCE, known as the Piora Oscillation, interrupted this. The Piora Oscillation had enormous consequences all across Asia, from enhancing a turn to millet in the west, to serving as a major stimulus for political consolidation under the Xia 夏 Kingdom in central China, and, probably, for the consolidation of many other local Bronze Age polities..$^{75}$ By 1200-150о BCE, climate change and possibly local overuse of resources led to a decline of agriculture and a regional "dark age." 76 In some areas of the West and Center, not until 500 BCE was momentum restored.

Meanwhile, the area now called Xinjiang showed a steady advance towards the formation of ever more complex and extensive societies. It seems to have

68 This is associated with advances in weaving and in a wide range of textile production. See Barber, "More light on the Xinjiang Textiles," in Mair and Hickman, Reconfiguring the Silk Road, 33-39.

69 Cunliffe, By Steppe, Desert, and Ocean, 78.

70 Cunliffe, By Steppe, Desert, and Ocean, 100.

71 Cunliffe, By Steppe, Desert, and Ocean, 98.

72 Cunliffe, By Steppe, Desert, and Ocean, 100.

73 Cunliffe, By Steppe, Desert, and Ocean, 136.

74 Baumer, The History of Central Asia, Vol. 1, 60-77, 104-106 gives fine illustrations; see also Andrew Lawler, "Central Asia's Lost Civilization," Discover Magazine, Online (2006).

75 Anderson (2019), The East Asian World-System: Climate and Dynastic Change.

76 Brite, "The Archaeology of the Aral Sea Crisis;" Kuzmina, The Prehistory of the Silk Road,. 74-75, 86-87. 
been unaffected by this Dark Age. By 3000 вСE China had barley, and probably the other major Near Eastern cultigens: wheat, sheep and goats. The barley appears in the Gansu corridor before 3000 BCE. ${ }^{77}$ It also shows up in a beer made with millet, Job's tears and roots in the Yangshao 仰韶 culture of central China by 3000 вСE. ${ }^{78}$ Rice beer was already known by then; China's brewing tradition is ancient and complex. Wheat apparently entered China through Afghanistan and Xinjiang. It probably entered via the steppes and Mongolia in the 3rd millennium BC, but the earliest known dates are still around 2500 BCE, ${ }^{79}$ as they have been for decades now. The Qijia 齊家 culture flourished at 2200-16oo ВСE, and west of it, the Siba 寺洼 in the Gansu corridor at 1900-150о вСE. ${ }^{80}$ These were both important cultures. Advanced for their time, they were important in establishing early links across the Eurasian heartland. Wheat and rye appear in the Gansu corridor before 2000 BCE..$^{81}$ Large communities and incipient states emerged in China about the same time, possibly stimulated by the cooler and drier weather, which forced people to concentrate around water and manage it carefully.

No later than 1500 вСЕ, China had the horse and chariot. These allowed the Shang 商 Dynasty to rise, around that time, and control the core of China-the center, along the Yellow River. Writing developed during this period; bronze working, which arrived from the Near East around 2000 BCE, was extremely well developed. Cities had large industrial zones for making bronze vessels, pottery, woodwork, bonework and other manufacturing. The art styles and technical achievements show Central Asian influence, and presumably this extended to the food, especially since wheat and barley were becoming widespread and popular.

Shang was replaced by the Zhou 周 Dynasty around 1050 BCE. This dynasty almost collapsed after $771 \mathrm{BCE}$, and several independent states arose, eventually becoming the "Warring States" of China's ancient period. It was in these that the most familiar aspects of Chinese intellectual culture-Confucianism, Daoism, poetry and art, dress styles, cosmological and scientific theoriestook shape.

In Central Asia, the distinctive pattern of extensive nomadism combined with intensive oasis farming and much less intensive upland farming was by

77 Barnes (2015), Archaeology of East Asia.

78 Wang, Li, Ball, et al, "Revealing a 5,ooo-year-old Beer Recipe in China," Proceedings of the National Academy of Sciences doi 10.1073/pnas.1601465113; 113:6444-6448 (2016).

79 Betts, Jia, and Dodson, "The Origin of Wheat in China and Possible Pathways for Its Introduction: A Review," Quarternary International 348 (2014), 158-168.

8o Cunliffe, By Steppe, Desert, and Ocean, 148.

81 Barners, Archaeology of East Asia, 417. 
then well established. Upland cultivation waxed and waned according to local climate fluctuations.

Mummified human burials are fairly common in the Tarim Basin of Xinjiang. They date as early as 2000-1800 $\mathrm{BCE},{ }^{82}$ but most are much later, around the beginning of our era. West of Mongolia and the "eighteen provinces" of traditional China, the population was generally Caucasian in appearance, as we know from these mummies and also from skeletons. ${ }^{83}$ In addition to revealing a bit about food, they reveal a great deal about culture contacts, trade and the possibility of food exchanges. The mummies not only look like Europeans but are dressed in clothing that would not be out of place in Europe at that time or later. Mummies from 1000 BCE wore wool clothes dyed with madder and indigo, notably early records for those dyes; ${ }^{84}$ the indigo would have been traded, probably from Central China. The clothes include some quite early trousers, and the analysts support an old view that trousers were invented for riding. ${ }^{85}$ These people were almost certainly Indo-European speakers, presumably ancestral Tokharians. The later mummies were buried with a good deal of food: wheat and millet products including dumplings and specially shaped small breads. The dumplings resemble modern Chinese jiiaozi 餃子 almost perfectly. Although beautifuly clothed, the mummies are not free from mummified lice. Agriculture associated with the mummies involved wheat and millets, goats and sheep, and cattle and camels. ${ }^{86}$

At this point, Indo-European loanwords may have entered Chinese, although the claim is not without controversy-early Chinese is not as wellstudied as it might be. Unlike the ancient Near Eastern languages, writing was not generally available in China until after $1800 \mathrm{BCE}$, and then it was only a proto-Chinese using early forms of characters that provide an imprecise indication of pronunciation. The least controversial Indo-European loan is $m i$ 蜜 (variously mie, mit in Chinese languages; EMC * mjit) for honey, from the familiar Indo-European root appearing as miel in Romance languages.

\footnotetext{
82 Cunliffe, By Steppe, Desert, and Ocean, 145.

83 Barber, "More light on the Xinjiang Textiles"; Kuzmina, The Prehistory of the Silk Road, 91-93; Mallory and Mair (2000), The Tarim Mummies: Ancient China and the Mystery of the Earliest Peoples from the West.

84 Kramell, Li, Csuk, et al., "Dyes of Late Bronze Age Clothes and Accessories from the Yanghai Archaeological Site, Turfan, China; Determination of the Fibres, Color Analysis, and Dating," Quarternary International 348 (2014), 214-223.

85 Beck, Wagner, Li, et al,"The Invention of Trousers and Its Likely Association with Horseback Riding and Mobility: A Case Study of Late 2nd Millennium вс Finds from Turfan in Eastern Central Asia," Quarternary International 348 (2014), 224-235.

86 Kuzmina, The Prehistory of the Silk Road, 93.
} 
Another likely borrowing from an Indo-European language is the literary word for a dog, quan 犬 in modern Chinese (EMC ${ }^{*} \mathrm{k}^{\mathrm{h}} \mathrm{wen}$ '). This would anciently have been pronounced very much like the Indo-European root *kiwon or * kwon (source of our English hound). ${ }^{87}$ Evidence for borrowing is that Chinese has its own pefectly good word for dog (gou 狗). Chinese apparently borrowed the word for elite dogs-noble hounds as opposed to plebeian gou. Loan words for "wheat, barley, horse, wheel, vehicle ...shepherd" and other words have been proposed by E. Pulleyblank, ${ }^{88}$ but these are highly tentative ( $m a$ 馬, "horse" from *marko-, the IE root of English "mare," seems likely; Mongolian morin probably comes from this source). There may be a problem of chance resemblances for such words. ${ }^{89} \mathrm{Mai}$, wheat and barley, by contrast, is not similar to any Indo-European word for grain, and is similar in both sound and graphic form to Chinese lai, "come," leading Chinese scholars to propose that these were "newly come" grains. The West did not borrow any Chinese words for millets, either. From the other direction, the Thai word for chicken, kai, spread along with that bird throughout much of Asia. ${ }^{90}$

There is other evidence for outside contacts as well. Vitally important for hunting and for defending herds was the improvement of archery technology. The composite bow entered the area perhaps around 1000-2000 BCE from outside $^{91}$ and revolutionized warfare. It is made from hard wood or horn, with hide or horn strips glued to the back to increase the strength. Two-hundredpound pull bows are not uncommon. It took years of training to be able to pull one, and stringing one could involve two or three strong men. ${ }^{92}$ These bows were short. They could be shot from horseback and in incredibly rapid volleys. Sultan Selim in Turkey shot an arrow 973 yards (more than half a mile) with a composite bow (Philip Wilke, pers. comm.; modern bows using modern specialized materials can shoot over 1100 yards). ${ }^{93}$ Later, crossbows - invented by northern Southeast Asian peoples at about the same time that composite bows reached, or were invented in, Inner Asia—spread to the steppe. Against such

$87 \quad$ Roots from Calvert Watkins (2000), The American Heritage Dictionary of Indo-European Roots.

88 Kuzmina, The Prehistory of the Silk Road, 96.

89 See Zhou (2002), Correspondence of the Basic Words between Old Chinese and Proto-IndoEuropean, for many very long reaches.

90 Blench, "Using Linguistics to Reconstruct African Subsistence Systems: Comparing Crop Names to Trees and Livestock," in Denham, Iriarte, and Vrydaghs (2007), Rethinking Agriculture: Archaeological and Ethnoarchaeological Perspectives, 408-438.

91 Golden (2011), Central Asia in World History.

92 See the discussion of the Mongol compound bow in May (2007), The Mongol Art of War.

93 See also the information at Archery History, <http://centenaryarchers.org.au/aboutarchery/the-basics/history/>. 
weapons, even early guns were hopelessly ineffective. Not until mobile cannons and rifles developed to reasonable standards did archers give way.

At this period, we begin to see spectacular tombs and grave goods. After 700 $\mathrm{BCE}$, rapid rise in urbanization began again, and contacts with the settled world to the west, south and east became more intense. ${ }^{94}$ From 900 BCE or earlier, animal-style art spread until it dominated the entire steppe region, from Europe to north China. Magnificent metalwork shows variously intertwined and distorted or mythologically portrayed animals (especially predatory felids and deer). Horse riders are often shown also. ${ }^{95}$ Surviving feltwork and carpets, from frozen tombs in the northern steppes, shows the same motifs. ${ }^{96}$ The Scythians (probably Iranic or at least including some Iranic groups) became famous for their magnificent goldwork, often copied from Greek or made by Greek craftsmen, although fundamentally an indigenous style. Scythian artwork remains some of the most spectacular in the world. ${ }^{97}$ The Scythians were classic horse nomads, herding stock over vast reaches of steppe and desert. The urban centers were places for nomad leaders to meet people from other parts of the world (Greek and Persian) and including nonnomadic professionals hired to support empires and states (craftspeople, priests, merchants and learned administrators). Their Western branches are well described by Herodotus.

Spectacular tombs in the Tuva area are not matched in Mongolia, although Mongolia too saw a slow, steady rise in number and complexity of burials, and associated with this, of craft and settlement. Wheat grains are found by 200 BCE. ${ }^{98}$ The wheat is presumably locally grown. The ironwork and pottery from the tombs and other archaeological sites are also local. It is not Chinese-made or -modeled. The Xiongnu state crystallized slowly from an increasingly dense and far-flung network. ${ }^{99}$ It may have been founded through war, as Chinese

94 Baumer, The History of Central Asia; Enkhtuvshin and Sanjmyatav (2007), Nomadic Civilization and Mongolian Bronze Age Monuments; Harmatta, Puri, and Etemadi (1994), History of Civilizations of Central Asia. Vol. II: The Development of Sedentary and Nomadic Civilizations: 700 BC to $A D 250$.

95 Baumer, The History of Central Asia; Piotrovsky (1976), From the Lands of the Scythians; Reeder (1999), Scythian Gold; Rudenko (1970), Frozen Tombs of Siberia: The Pazyryk Burials of Iron-Age Horsemen.

96 Rudenko, Frozen Tombs of Siberia.

97 And see Baumer, The History of Central Asia, 182-183, for the most preposterously romantic Russian painting imaginable of Scythian life.

98 Honeychurch, "The Nomad as State Builder: Historical Theory and Material Evidence from Mongolia," Journal of World Prehistory 26 (2013), 283-321 (308).

Honeychurch, "The Nomad as State Builder." 
records state, but archaeology shows a gradual process of political-economic growth, not a wild and woolly battling of steppe nomads.

A Dark Age in the western and central parts of our region caused a sharp, dramatic reversal of progress into town and village life. It was probably at least in part due to worsening of climate around 2200-2000 BCE, but locally did not start till later. It ended by 5 Оо вСE; it did not visibly affect the East.

The foods associated with these developments are what one would expect: the staples are still important in the region. A typical site of this period is Tuzusai in Kazakhstan. Around 400-100 BCE it was growing wheat, barley of various types, both millets, and grapes. It occupied a very lush environment on a fertile, well-watered alluvial fan in the Semirech'ye, $15 \mathrm{~km}$ east of modern Almaty. (The Semirech'ye, "Seven Rivers," is the area that drains west into Lake Balkash.) Wild plants eaten included sea buckthorn, wild plum, wild cherry, and others. ${ }^{100}$

From Bronze Age and Iron Age times, or even earlier, come the many origin stories of local people. Most descend from totemic animals, usually ones that are transparently symbolic of desirable qualities: men are (or were) wolves, bears and eagles; women are deer and other beautiful, gentle beings.

Typical of such mythology are the tales of the Khitan, who ruled north China in the 11th century but whose stories are much older than that. They duly recorded their history in the sober, formal historical annals so dear to imperial China. These tell us that a man riding a white horse and a woman riding a gray cow got together at the sacred mountain where the sacred rivers join. One may speculate that the original myth had only the horse and the cow begetting the Khitan. Among the early kings of the Khitan was one who was just a skull. He took human form only for the annual sacrifice, when in proper totemic style a white horse and a gray cow were sacrificed for the ancestral ones. Another king had the head of a boar. Another always had 20 sheep; every day he ate 19 of them, the next day there were 20 again.

Abaoji 阿保機, is the first Khitan king who has some claim to have been a real person. He was born of a sunray, had the body of a 3-year-old at birth, could crawl on all fours as soon as newborn (remember these are horse nomads, and horses can run within hours of birth), and could walk after three months. At one year he could speak, and foretell the future. ${ }^{101}$

100 Spengler, Chang, and Tourtellotte, "Agricultural Production in the Central Asian Mountains: Tuzusai, Kazakhstan (410-150 BC)," Journal of Field Archaeology 38 (2013), 68-85; Spengler, Frachetti, and Fritz, "Ecotopes and Herd Foraging Practices in the Steppe/ Mountain Ecotone of Central Asia during the Bronze and Iron Ages," Journal of Ethnobiology 33 (2013), 125-147.

Sinor (1998), "The Kitan and the Kara Khitay," 228. 
Religion has greatly influenced Central Asian foodways. The most obvious way is through Muslim bans on pork, alcohol, and some other foods. Buddhism was also a major influence, by stimulating dairy production, introducing Indian foodways, and promoting abstemious living. Vegetarianism could not flourish outside of a few monasteries; there simply was not enough vegetable food available. Buddhism also led to restraint in hunting game. It was instrumental, for example, in preserving vast game herds in Tibet; the recent Chinese occupation of Tibet and repression of Buddhism has led to rapid extermination of those herds. Buddhism has had similar effects in Mongolia. Earlier religions preserved game there too. Even Manichaeanism, rare and little known in most of the world, although influential in pre-Islamic Central Asia, influenced foodways. Mani (ca. 216-274), its prophet, taught that cucumbers and melons concentrated the Light — the good and holy. ${ }^{102}$ This is one source for the enormous popularity of those vegetables in the oases of the region.

In ancient times, the Eurasian heartland was a vast melting-pot of religions. The basic faith of the area was shamanic veneration of sky, mountain, weather, and nature spirits. This faith very much persists in Mongolia with its thousands of ovoo (or obo), cairns dedicated to the local spirits. This created a basically tolerant attitude. Before the triumph of Islam, beginning in the 8th century, the area was home to Christianity in several forms. Later it was home to Zoroastrianism and Judaism, then to Buddhism again in several forms. There was also Daoism, Manichaeanism, and various local traditions. Richard Foltz, in Religions of the Silk Road (2nd edn. New York, 2010), has provided an excellent overview of this wonderful openness.

The Persians under Cyrus introduced this Inner Asian idea to the West. His "Cyrus cylinder" is the first known statement of religious tolerance by a government.

Freedom of religion was a striking characteristic of the nomadic world. ${ }^{103}$ It was remarked on, often unfavorably, by Christians and Muslims in the Medieval period. No large-scale polities on earth, until very recent times, have been so completely free of religious bias. The Cyrus cylinder was a decree of the king of Persia around 539 BCE; the Persians had recently invaded from the steppes. The spread of Islam at first mattered relatively little, as Central Asia embraced a particularly liberal form of that faith. Over time, theological changes reduced

102 Gignoux and Litvinsky (1996), "Religions and Religious Movements - I," 403-420 (414).

103 Biran (2005), The Empire of the Qara Khitai in Eurasian History: Between China and the Islamic World. 
this religious tolerance. The spirit has persisted. Religious openness in Islamic areas diminished after 1100, but Turkic rulers maintained considerable tolerance even in Europe and India. The Turkish Empire was famously a refuge for religious minorities persecuted elsewhere. Akbar revived steppe freedoms in India in the 16th century, eventually starting his own fusion religion. Only recently, as a response or reaction to Christian or Communist conquest (notably, but not only, Russian), did Central Asia begin the slide in some areas into a more extremist, repressive version of Islam.

Turkic and Mongol worship of Heaven made them broadly tolerant, interested in all religions, and willing to welcome all and listen to open debates. ${ }^{104}$ Indeed, the strict Central Asian thinker al-Ghazālī (1058-1111) maintained (with some exaggeration) that the Turks would fall down before anything really beautiful and say, "It is our Lord!"105 The Mongol emperors were famous too for their religious tolerance.

Mongol religion is based on worship of Heaven, tengri, and thus has been called "Tengrism." It also, however, involves reverence for all nature. Mountains, trees, streams, even rocks, and herbs have powerful indwelling spiritual presences. ${ }^{106}$ These must be respected. Shamans still exist who can contact these spirits, especially when in trance states. The food relevance is there: Tengrism teaches respect for all beings, including game and fish, and that means restraint in hunting-one cannot take too much. This has limited game consumption, thus saving the game and fish for the future. Domestic animals too get considerable respect, shown by relatively good treatment.

Ancient Turkic religion was similar, and derivatives of it survive in Siberia. Further consideration of religion is somewhat outside the bounds of this book. Readers should consult Caroline Humphrey's wonderful studies of Mongolian religion. ${ }^{107}$

Since the early Medieval period, religion in Central Asia outside of Mongolia means Islam. Traditional Islam in Central Asia is overwhelmingly Sunni, of the Hanafi legal tradition. Sunni Islam has four different traditions of interpreting the Sharia. They have their own sub-traditions. Hanafi is one of the most liberal. The old Hanafi Islam of early Medieval central Asia was

\footnotetext{
104 See e.g. Biran the Empire of the Qara Khitai, 180-191.

105 Baldick (2000), Animal and Shaman: Ancient Religions of Central Asia, 51.

106 Roux (1984), Religion des Turcs et des Mongoles (Paris, 1984); Roux (1966), Faune et flore sacrées dans les sociétés altaïques.

107 Humphrey (1995), "Chiefly and Shamanist Landscapes in Mongolia," 135-162; Humphrey and Onon (1996), Shamans and Elders: Experience, Knowledge, and Power among the Daur Mongols; Metzo, "Articulating a Baikal Environmental Ethic," Anthropology and Humanism 30 (2005), 39-54.
} 
particularly tolerant. This is related to the earlier openness of the region. The right-wing Islam increasingly dominant today began long ago, with the theologian al-Ghazālī a key figure. It grew serious only when extremist "Wahhabi" interpreters of the Shari'a took over Saudi Arabia, and spread their views in the Russian, and later Soviet, periods, as a form of resistance to Russian rule. ${ }^{108}$ It has intensified even more since, especially in Afghanistan. In Xinjiang, the Russians were not a force. Chinese Communism has cracked down harder and harder on Islam, and the few terrorist outbursts have only caused more and wider repression.

Sunni Islam dominates in most of Central Asia. Shi'a Islam is common among several remote montane minority groups, especially in Afghanistan. It is dominant among Iranians, including those in western Afghanistan and elsewhere. Shi'a differs from Sunni largely in recognizing, in early Islam's history, the authority of the Prophet's family rather than his initial companions. It has its own interpretations of the religious law and its own subdivisions.

Islam has powerfully influenced Inner Asian foodways by its bans on pork and alcohol. Formerly, pigs were grown in the river valleys; wines (grape, pomegranate, and other), and beer-like grain drinks, were universal. This all disappeared with the coming of Islam in the 8th century, though wine-drinking persisted quite enthusiastically in many areas, principally those showing a great deal of Iranian influence. The liberal Hanafi tradition was not harsh in condemning it, and many lax Muslims and — in early days - covert shamanists and Zoroastrians consumed it enthusiastically. Today pork is largely raised by Russians for Russian consumption in Kazakhstan. Another influence was on water supply; Islamic law, adapted to desert environments, has a highly enlightened and sophisticated set of rules about water use, and this influenced the development of irrigation and water management. Until the USSR upended them, highly enlightened local and state rules on water use were widespread, and shortage of water was not common, despite the harsh desert environment.

A survival of ancient "pagan" Indo-European religion is found in the remote mountains of northern Pakistan among the Kalash and their neighbors. Many of the deities are identifiably cognate with ancient Greek ones. The main stronghold of this religion was in Afghanistan until the late 19th century, when the region was conquered, subdued, and Islamized. Fortunately, an exceptionally good early ethnographer, George Robertson, did a thorough local study 


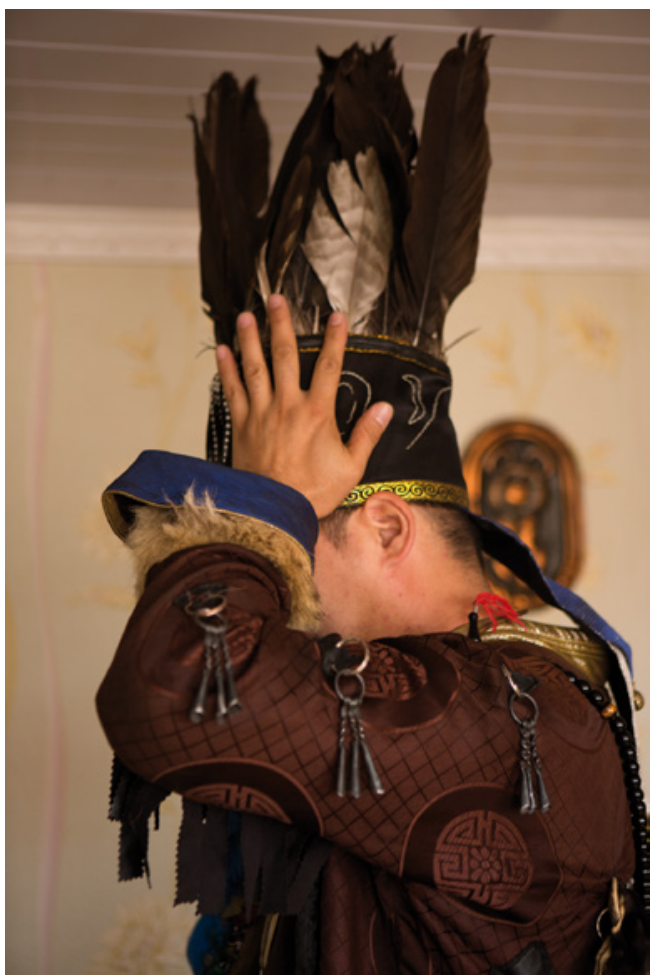

Рното 24

A Mongolian shaman in traditional attire

before old ways were lost. ${ }^{109}$ A distinctive culture still exists there, with woodcarving and wood technology conspicuous. The languages of these groups form a distinctive branch of the Indo-Iranian family (closer to Indian languages than to the other languages of Afghanistan). The people live on wheat, with some millet and maize. They also lived on livestock, dairy foods, and tree crops including lots of walnuts. They consumed a great deal of wine and had ritual feasts involving the consumption of domestic animals, especially goats and various breads. Religion structured every aspect of producing and consuming food. ${ }^{110}$

109 Robertson (1896), The Kafirs of the Hindu-Kush; see also Jones (1974), Men of Influence in Nuristan; Maggi (2001), Our Women Are Free, for later information, including food.

110 Jones, Men of Influence in Nuristan. 